\title{
13
}

\section{ETHNOGRAPHY, ARTS PRODUCTION AND PERFORMANCE}

\author{
Meaning making in and for the street
}

Jessica Bradley

\section{Introduction}

This chapter considers how ethnographic approaches to creative practice, in this case devised street theatre, might enable new understandings of communication. In focusing on the theatre of the street it demonstrates how people draw on their communicative (Rymes 2014), or semiotic (Kusters et al. 2017) repertoires to produce creative work. It also sheds light on how short-term, intensive periods of research might be embedded within a longer-term commitment to working with research participants (see also Bradley 2017a). In choosing to foreground methodology, reflections on processes, and significant moments during the production process, it offers insights into ethnography as transdisciplinary dialogue. It therefore contributes an innovative methodological approach, interweaving ethnographic research with the wider contextual space of collaborative working with creative practitioners. This demonstrates the possibilities for engaging across sectors in gaining deeper understandings of the intersections of arts practice and language.

The data and reflections in this chapter derive from a doctoral research project with street arts performers in the UK and Slovenia, which considered language use in relation to the entanglements of bodies, objects and space. The main fieldwork took place in Ljubljana, Slovenia between March and July 2015 (Bradley 2018). The research was part of a wider multi-site ethnographic project which investigated multilingual communicative practices across superdiverse cities in the UK (TLANG, PI Angela Creese 2014-2018), funded by the UK's Arts and Humanities Research Council (AHRC) under its Translating Cultures theme. The TLANG project methodology was underpinned by linguistic and visual ethnography with researchers situated across four cities working with key participants across four different broad areas of activity: business, heritage, sport and law (e.g. Baynham et al. 2015). My own study, as part of this broader research, was to focus on community 
arts and my research centred on the creation of a street arts performance. This performance was devised and performed by a UK-based community arts organisation and a Slovenia-based street arts theatre as part of a wider collaborative project around street arts education in Europe (Adams 2015).

In this chapter I first pay attention to the stages of production, how these were developed during the observations I undertook and how they worked to frame the analysis. I then consider the theoretical concept of translanguaging, bringing it together with ethnography. This is followed by focusing on short-term immersion in research, in the context of longer-term engagement. I illustrate my arguments using excerpts of data and return to the questions posed at the beginning of the chapter.

\section{The stages of production}

Over a period of five months, professional and aspiring performers worked together to create and perform a production, led by the artistic director of a UK-based arts organisation. This was based on a traditional story told by one of the performers during one of the initial project workshops (see also Bradley 2017a). This traditional story was a cautionary tale about a mythical goat with golden horns Zlatorog - whose anger at the impulsive acts of humans destroys the paradise of the Julian Alps (see Copeland 1933). As the production process progressed, the story was transformed into a series of multiple, co-existing and intertwined texts, propelled onwards by the performers. Although the process of producing a theatre piece for the street was fluid and emergent, I organised the activities into four stages, as emerging from my observations over the course of my fieldwork and through dialogue with the artistic director. In this way I developed a model for understanding the different stages of production which aligns generally with the kinds of practices and negotiations involved in creating a production. Across these stages, which also formed the analytical core of my thesis, I incorporated different analytical tools to gradually encompass the performers' multimodal, multilingual and multisensory practices. The stages are summarised as follows:

- First, the conceptualisation stage, during which the performers shared stories of place (including the story of Zlatorog), the aim of which was to find the starting point for the production itself (March 2015).

- Second, the making stage, which was characterised by activities to create costumes and puppets and finding source material for props and objects to tell the story (May 2015).

- Third, the devising stage, for which the focus was co-designing the production itself, allocating parts and rehearsing the performance (June 2015).

- Fourth, the performance, which took place across villages, towns and cities in Slovenia as part of an international street arts festival (June-July 2015).

Dividing the activities by stage was in many ways artificial, imposing borders that were time- and space-bound but not necessarily able to describe the fluidity of the 
activities under investigation. The stages were porous. The activities which defined them were not necessarily restricted to a particular time period or location: for example, making took place across all four stages. But methodologically they provided scaffold for the analysis, imposing a structure on the creative process. In this chapter I focus on a small extract of interactional data taken from a conversation which took place at the beginning of the second stage of production: making. First, I set out the context for my research, translanguaging as the guiding concept and short-term ethnography as a methodological and epistemological strategy.

\section{Context: extending the translanguaging lens}

Translanguaging was an initial focus for my research (see also García and Li 2014; $\mathrm{Li}$ 2018). As a theoretical concept that has gained significant traction, translanguaging is one of a number of ways of describing, analysing and theorising dynamic multilingual (and multimodal) practice. These include metrolingualism (e.g. Pennycook and Otsuji 2015), polylanguaging (e.g. Jørgensen et al. 2011) and plurilingualism (cf. García and Otheguy 2019). Li Wei highlights translanguaging's multimodal and multisensory nature (2018). Trans- approaches to all kinds of areas of social life are highly prevalent, and include, as Hawkins and Mori (2018, 1) state, concepts such as "transnational, transcultural, translocal, transpatial, transmodal, translanguaging, and translingual". Hawkins and Mori go on to suggest that trans- works to extend ways of understanding the flexibility and fluidity characterising society, opening up possibilities for understanding communication and social action.

Translanguaging is therefore one of multiple concepts which aim to offer a holistic lens for understanding fluid communicative practice. Much critiqued (e.g. Pennycook 2016; Jaspers 2017; Auer 2019), its application across a wide range of contexts has pushed it to outer limits, going beyond not just named languages but also language (e.g. Li 2018). Li $(2018,9)$ suggests that its broad take up could risk it seeming interchangeable with other sociolinguistic analytical constructs or indeed that it might compete with other terms, a critique which aligns to some extent to those made by Peter Auer (2019), whose concern is that translanguaging's differentiation from codeswitching is misconstrued (see also MacSwan 2017). Li underlines that translanguaging offers more than a description of communicative practice and is instead what he describes as a "practical theory of language" (2018). It is not within the scope of this chapter to critically engage with the theoretical and disciplinary discussions around the concept and what it can and cannot encompass. Rather, and crucially for the activities under investigation in my research and foregrounded in this chapter, translanguaging offers significant transdisciplinary affordances as Li explains:

Ultimately, Translanguaging aims to present a new transdisciplinary research perspective that goes beyond the artificial divides between linguistics, psychology, sociology, etc, and as such it requires analytic methods that move the focus 
away from treating languages as discrete and complete systems to how language users orchestrate their diverse and multiple meaning- and sense-making resources in their everyday social life. (Li 2018, 27, emphases added)

Lou Harvey (2020) takes the notion of trans- further in an analysis of reworking narrative research in language education for performance in collaboration with theatre practitioners, suggesting "entangled trans-ing" as concept to account for the transformative potentialities of translanguaging, attending to voice, narration and authorship. So, as many scholars are arguing (e.g. Hawkins and Mori 2018; Harvey 2020), trans- approaches offer potential for opening up new ways of thinking about the complexities of communication.

My own research examined how, in line with current theories of dynamic multilingualism, attention might be paid to the multimodal and the material, extending the analytical lens towards the multimodal practices of the creative practitioners through following the story of Zlatorog as a thread. Of course, for my research with street performers, many of the practices I observed were non-verbal and highly visual. Trans- approaches in research offer a way to holistically encompass these dynamic and creative communicative practices which go "across, through or beyond" (Jones 2016, 2) languages and language. I adapted a posthuman lens on translanguaging, incorporating the New Materialist concept of intra-action (Barad 2007) into a translanguaging perspective on communicative practices in street arts production and performance. This shifts the focus towards "the mutual constitution of entangled agencies" (Barad 2007, 26), presupposing that agencies are not independent: "they don't exist as individual elements" (ibid.). But, as demonstrated through imposing stages on the production process, there are also risks in eliminating categories and destabilising boundaries. What happens if we attend to wider semiosis in translanguaging (e.g. Pennycook 2017)? We may gain significantly in terms of our scope and what gets included in our analysis. However, we may also lose something important: there are gains and losses (cf. Kress 2005). As Ofelia García (2020) cautions, how can researchers committed to breaking down structures which increase inequalities foreground the embodied experiences of languaging by language-minoritized communities, whilst also destabilising bounded notions of named languages? Is there a risk that these actions might be in opposition? These questions are central to my research.

I will now reflect on ethnography as an underpinning approach to my research, pivotal to the questions raised above, problematizing it and highlighting some of the challenges I encountered during my fieldwork.

\section{Ethnography, translanguaging and transformation}

In an article setting out some directions for ethnography within the context of Modern Languages, Naomi Wells, Charles Forsdick, and colleagues state that "the openness and curiosity on which Modern Languages are founded are, in many ways, ethnographic impulses" (2019). The authors go on to suggest that a 
"transformative" ethnographic approach to Modern Languages is urgently needed, contributing to a "public idea about language" in Mary Louise Pratt's terms, "which goes beyond an instrumental focus on language skills" (ibid.).

Although in this example Wells and colleagues are focusing on Modern Languages as a discipline, the argument that ethnography can create spaces for us not only to reflect on what we do but also interrogate it applies much more broadly. The authors describe ways in which ethnography is and might be incorporated within research, teaching and public engagement with research, even in shorter time periods. Incorporating ethnography in the ways described in the article makes the case for a trans- approach to activities within the field, disrupting some of the artificial boundaries set up between languages as defined by nation states (see also Bradley $2017 b$ ). The authors therefore argue that ethnography enables deeper understanding of the fluid communicative practices we deploy in our everyday lives, pushing to observe "beyond" the languages themselves. This underpins linguistic ethnographic approaches to research (e.g. Copland and Creese 2015) as opening up and extending aspects of linguistic analysis (cf. Rampton et al. 2014). So, if ethnography, as an approach to understanding communication in context in everyday lives, is compatible with translanguaging as a concept, what can focusing on street performance bring?

\section{Short-term immersion, longer-term engagement: approaching street arts production and performance from ethnography}

In conceptualising the four stages of production for the process of creating the street arts performance, I sought to bound what were short, immersive periods of ethnographic fieldwork embedded within a longer-term commitment to working with the creative practitioners. I considered these time-bound periods of ethnographic research as "short-term ethnography" following Pink and Morgan (2013). Ethnography is a long-term undertaking, in some cases a lifetime's work. Moreover, doing ethnography is often painstaking and emotionally complex work, requiring many years of engagement. During the first year of my doctorate I was advised that in order to be able to call a piece of research an ethnography it must be long-term, intensive research, indeed perhaps longer than a doctoral research timescale would ever allow. Tensions therefore arise - how can a long-term ethnographic project fit not only into a doctoral research project but also into a life, in which multiple priorities compete? A critical approach to ethnography allows reflection on what insights ethnographic research might offer and what might also be missed. The concept of short-term ethnography accepts that ethnographic research is always constrained and always partial. Pink and Morgan explain that "short-term" ethnographic approaches are different from "quick and dirty" approaches to research. They situate it theoretically within what Pink $(2009,354)$ has called the "ethnographic place", a concept which seeks to "explain how a range of different types, qualities and temporalities of things and persons come together as part of the process of the making of ethnographic knowledge or ways of knowing”. 
As Pink and Morgan state, there are ways of working in even short-term, intensive and immersive contexts which in fact involve ethnographic engagement on a much wider scale and for the longer term. They describe four aspects of short-term ethnography as a starting point for further engagement. These are summarised as follows:

- the intensity of the research encounter, or "encounters with moments in other people's worlds" (Pink and Morgan 2013, 356) as learning and empathy;

- the different possibilities for focusing in detail in contexts in which the researcher cannot possibly learn how to "do" the practice under investigation;

- the ethnographic-theoretical dialog, as developing through continuous engagement (ibid., 358); and

- the use of audiovisual technology as "traces of ethnographic encounters" (ibid., 358).

Again, these features are perhaps artificial. But they allow for an exploration of the ontological possibility of short-term ethnography, not, as the authors argue, as a replacement for longer-term engagement but as something with distinct affordances.

Beyond the four stages in my research into street arts production, intense encounters with the worlds of the performers were embedded within the context of creating a series of collaborative projects with the organisation's artistic director (see McKay and Bradley 2016; Bradley et al. 2018), therefore extending far beyond the five-month fieldwork period. I did not (and could not) train to do street theatre myself while undertaking my research. However, I did participate in other ways: the time-bound nature of the production process meant that I was entangled in elements of the activities, for example in making props and costumes. There was an "all-hands-on-deck" approach. I sewed long strips of fabric onto puppet wigs and daubed detail with pink paint onto large puppet hands made from ping-pong bats. The rapid collection of data took place alongside engagement with theory, with the analytical framework developing across the process in dialogue with the ethnographic encounter and the data. Data collection across the process of the longer-term collaboration, but in particular during the four stages, included video and audio recordings, again, allowing me to return to the data in a way which will inform my work for years to come. Researching in this way - moving backwards and forwards from the data corpus, to theory and to the ongoing projects I worked on with Bev - foregrounded the tensions in ethnographic research in general. This enabled me to build constructive relationships, making deeper insights possible than the initial fieldwork would allow. In this sense, the ethnographic place was extended and complexified: an entangled ethnographic place. But that is not to say that this approach was without its challenges. I noted the following during my fieldwork which expresses some of how I felt about what I considered to be the partiality of my lens with regards to particular challenges faced by the performers: 
I am participating and observing. But I am also missing so much. This raises questions for me about the partiality of any kind of observational research and the partiality of ethnography in terms of the "slice" of experience I am documenting and analysing. It poses interesting challenges for how I, as researcher, might write about these tensions, clearly inevitable in any kind of collaborative process. I am conscious of my "invited" presence. (Fieldnotes, May 2015)

In some ways I created different tensions through my presence. But with ethnography the partiality is also foregrounded - and can and should be accounted for, reflexively, as I wrote in my thesis:

And yet, the writings presented in the four analytical chapters are interpretations of these agencies, as considered through particular lenses, each one partial. As Geertz puts it, "in short, anthropological writings are themselves interpretations, and second and third order ones to boot" (1973, 317). (Bradley 2018, 288)

With all research, and particularly in the case of short-term ethnography, the partiality of the ethnographer's gaze and of any analysis must be considered. The data present new questions and new challenges. As Maggie MacLure states, data here are emergent - in ethnography they ask "what next" $(2013,228)$.

My research, and short-term ethnographic research of this kind, represents what Monica Heller (2008) describes as a slice of experience. It is a slice of a story, or multiple slices and perspectives on a story, that is told and retold many times and in different ways. It seeks to understand how the performers do the things they do, why they make the choices they make and what else is at play. But my research is also my own stories of these slices of experience. As with all ethnography, even longer-term, "life-project" ethnography, it is incomplete. It aims to shed light on communicative practices and processes but it also aims to disrupt and develop new ways of thinking about translanguaging and its affordances for understanding these complex processes of production and collaboration. So, I situate the approach I take to my research as ethnography. But I do so cautiously and critically, with the awareness that, as Tim Ingold (2017) states, ethnography can be constraining and speculative:

But in what I write I can at least argue for what I consider to be true, or as close to the truth as I can attain, in the light of my reading, the conversations I have had, and my own critical reflection. (Ingold 2017, 23)

A commitment to researching with people and, therefore, to engaging in common activities with people is also a commitment to providing evidence for the claims we make and accounting for our observations (Miller 2017). But, as Ingold argues, it is not necessarily a commitment to represent the views and opinions of the people with whom we have been working - and herein lies another tension. Instead I present these slices of experience through the analysis 
of the decisions and processes behind each series of transformations across the production process. The analysis reflects my reading, my conversations, my observations, and my own critical reflection, an "ethnographic-theoretical dialog" (Pink and Morgan 2013). It is, in this sense, my interpretation of research findings developed through "educational correspondence" (Ingold 2014, 393). In my research (which is always an account of other texts, a travelling story) I do not claim to speak for the people with whom I have been engaging in "educational correspondence". Instead, I speak for myself, through the training and intellectual development that has opened up for me through engaging in ethnographic research. The process is therefore both "experimental and interrogative" (Ingold 2017 , 24). Although not a street performer, as a researcher I contributed to many of the stories I write about and I seek to make this visible through reflexive engagement with my work (cf. Grenfell and Pahl 2019).

Having positioned my research theoretically and methodologically, I will now reflect on a number of challenges and opportunities which arose through this project. I have categorised these as humiliation of the anthropologist (Miller 2017) and the opportunities in unsettledness (Shuman 2011).

\section{Deep hanging out: opportunities in humiliation and unsettledness}

Investigating the processes involved in creating a street arts production required what Clifford Geertz (1998) describes as "deep hanging out" with artists, performers, and people who are learning to be these things and do these things. Over the course of this process, I collected multiple modes of data, including observational notes, video recordings, audio recordings, photographs, vignettes, blog posts and interviews. This enabled me to develop different understandings of the complexity of what was happening within these short-term projects. The range of data and the approach described earlier, enabled me to better situate how these smaller projects function within the wider context of the collaborative relationships, of the broader frameworks (e.g. streets arts festivals and training programmes). I was able to investigate how the objects, the material, can be seen to embody the interweaving of histories, of practices and how the processes represent the meshing of wants, desires, and strategies. And how communication in its broadest sense is central to the process (the production) and to the product (the performance itself). In this sense, the methodology I developed through my research mirrored the practices of the performers with whom I was working.

As my research continued, I began to realise that I needed to work to de-centre language (e.g. MacLure 2013). From the outset I had made a theoretically-grounded decision to commit to working with a group of people, therefore following their lead and their activities. I could have developed this research in other ways, for example by taking a place-based approach. In this case I would have situated myself within a particular geographically-defined space, perhaps a cultural institution or a community centre, and observed the comings and goings of different people within that space. Both these, or even a combination of the two, would be legitimate methodological approaches. But in choosing to work with mobile people, whose work crossed the borders of arts 
"institutions" and who create work in public and often disputed spaces, I accepted that I would not necessarily know what the context might look like, and indeed that it might not look as I expected. Daniel Miller describes this process - the act of not finding what we're looking for - as "the humiliation of the anthropologist" $(2017,28)$, suggesting that this is something we should welcome:

A problem for contemporary anthropological practice is that a student may be expected to spend up to a year preparing to study a topic of current anthropological concern, but almost inevitably when they get to their field site this proves to be completely different from what they expected and most of that initial preparation turns out to have been inappropriate. (Miller 2017, 28)

I followed where others led, hoping to commit "generous attention" to the activities and practices (see Bradley 2017a). There is a risk in doing research in this way and a risk of humiliation. However, in researching creative arts and working with creative practitioners the contexts are uncertain, often led by specific projects reliant on external funding. People do not necessarily do what you decided they ought to do in your research plan. Pink and Morgan (2013, 352) suggest that the contexts in which researchers are embedded "shape" ethnography, making it "slippery to define". There is therefore the combination of liquid contexts and a liquid approach. The approach takes on the characteristics of the contexts, requiring an openness and acceptance of this risk.

So doing ethnography might mean accepting degrees of unsettledness, discomfort and being on the verge (Shuman 2011). But this also means being open to rich opportunities for collaboration, enabling the exploration of spaces and places that would not necessarily been envisaged or conceivable at the outset of the research process. This includes the emergence of data in unplanned spaces. To exemplify this, I will now focus on a small extract of data taken from a conversation in a taxi during the making stage of the production process.

\section{Conversations betwixt and between}

Over the course of my fieldwork I undertook a number of interviews as part of the broader data collection. The role of the interview in ethnographic research is an interesting one (e.g. Hammersley and Atkinson 1983; Conteh 2017), with Martin Hammersley and Paul Atkinson suggesting that ethnographers do not need to "shy away from interviews" $(1983,131)$ as a way of offering insights into the "perspectives of the participants in the context" (Conteh 2017, 32). In the main these were "go along" (Kusenbach 2003), taking the form of "structured conversations" (Conteh and Toyoshima 2005, 23). In many cases I did not consider these "chats" as interviews until afterwards. To me they were conversations that would allow me to better contextualise the practices and processes I was investigating. But, later on these short snippets of conversations became more central to the analytical process, offering particular insights. The table below (Table 13.1) shows the different methods I used across the stages of production: 
TABLE 13.1 Data collection across the stages

\begin{tabular}{ll}
\hline Stage of production and location & Research method and data collected \\
\hline Stage One: Conceptualisation & Participant observation of workshops \\
Tabor, central Ljubljana, Slovenia & Fieldnotes, video recordings of workshops, video \\
& recordings of interviews, photographs, fieldnotes. \\
Stage Two: Making & Participant observation of workshops and par- \\
ticipation in making activities & Fieldnotes, video recordings of activities, video \\
Studio, Šiška district, Ljubljana, & recordings of interviews, photographs, audio \\
Slovenia & recordings of activities, audio recordings of inter- \\
& views, audio recordings of conversations, fieldnotes, \\
& reflective vignettes. \\
& Participant observation of workshops \\
Stage Three: Devising & Fieldnotes, video recordings of activities, video \\
Tabor, central Ljubljana, Slovenia & recordings of interviews, photographs, audio \\
& recordings of activities, audio recordings of inter- \\
& views, audio recordings of conversations, fieldnotes, \\
& reflective vignettes. \\
Participant observation during festival: back- & stage and performances \\
Stage Four: Performance & Video recordings of two performances, audio \\
Ljubljana streets and Tabor, central & recordings of interviews, audio recordings of con- \\
Ljubljana, Slovenia & versations, photographs, fieldnotes, reflective \\
& vignettes.
\end{tabular}

The example here is taken from a conversation between the artistic director, Bev, and me in a taxi from Ljubljana airport to the city centre. The conversation concerns setting out ideas and plans for the following days of making and devising. The data were audiorecorded and later transcribed. At the time I had not necessarily considered this conversation as an interview or as data. I was experimenting with recording conversations during the periods of time I referred to as "liminal" (cf. Turner 1969). This is one example of many interactions in transit. These moments emerged as more significant than I had originally thought with data presenting themselves in "surprising ways" (MacLure 2013, 231). This often occurred in opposition to the categories I sought to impose on my data. I gradually learned how to let the data speak and be open to my own engagement with them, to attention and experimentation, as MacLure puts it: "we need to be attentive and open to surprise to recognise the invitation; and once invited in, our task is to experiment and see where that takes us" (ibid.).

The taxi journey presented an opportunity for me to ask about how the production would develop. I wanted to understand more about the synopsis and plans for the following few days. Bev explains how she has conceived the story as it will be told and animated by the performers. Although an elicited narrative, it arose in natural conversation and multiple "small stories" emerge in the conversation (see Table 13.2). 
TABLE 13.2 Data excerpt, conversation in taxi, May 2015

\begin{tabular}{|c|c|c|}
\hline 1 & $J:$ & Okay \\
\hline 2 & B: & $\begin{array}{l}\text { So when I wrote that little synopsis (.) what was (.) really important for } \\
\text { me is to break down quite a complex (.) narrative into a series of action } \\
\text { points? }\end{array}$ \\
\hline 3 & $\mathrm{~J}:$ & Yeah \\
\hline 4 & B: & $\begin{array}{l}\text { So that }(.) \text { it's }(.) \text { you know it's very simple even there's a there's not a lot } \\
\text { of }(.) \text { there's a few bits of }(.) \text { description }(.) \text { as in the character or setting } \\
\text { (.) but it's (...) so and so comes and does this (...) and then does that (.) } \\
\text { and then (.) this happens } \\
\text { [It's very] (...) }\end{array}$ \\
\hline 5 & $\mathrm{~J}:$ & [Okay] \\
\hline 6 & B: & $\begin{array}{l}\text { Kind of }(.) \text { clear }(. . .) \text { so that }(.) \text { you don't }(.) \text { because when you then } \\
\text { perform it you can put loads [into it] }\end{array}$ \\
\hline 7 & $\mathrm{~J}:$ & [Yeah] \\
\hline 8 & B: & Makes it very clear what that (.) action is \\
\hline 9 & $\mathrm{~J}:$ & [Okay] \\
\hline 10 & B: & [Action] to action $(\mathrm{xxx})$ \\
\hline
\end{tabular}

I re-initiate the conversation (okay) (1). We had started to talk about the plans already and I had asked whether I could record. Bev had laughed and agreed. She then starts to explain her rationale for writing a short synopsis which set out the production ideas that she has sent to the Ljubljana-based street theatre and to me previously prior to travelling. She had taken the story that will be used for the production narrative, Zlatorog, and, seeking to simplify it, created what she calls "action points". The purpose here had been to simplify the story and break it down into actions by each character (4), divided into paragraphs. Bev had worked from a number of sources, including the notes she had made during the initial telling of the story which took place during the conceptualization stage. For this Bev had also drawn on an article about the story I had sent her by the author and academic (and climber) Fanny Copeland from the 1930s and from the video I had made of the performer telling the story.

Bev explains that creating short actions is a way of making the story "clear" (6). Clarity of story-telling is important for a street arts production: the audience must be able to follow the story and understand what is happening in a busy street context. The translation of the text into a synopsis also functions to enable the performers to know what they must do at each point and the action they must execute.

\section{Discussion and implications}

This chapter was framed around three questions and how these are explored in my research. Here I consider each question in light of the theory, approach and slice of analysis shown above. I then describe the implications and future directions for my research. 


\section{How might ethnographic approaches to creative practice enable new understandings of communication?}

The first of these questions engaged with the transdisciplinarity of arts-based research and how ethnography enables new understandings of communication. Although the data derive from short-term engagements with practitioners, there is no quick way to engage with creative practice and it requires approaching research design in ways which allow for the open-endedness and emergence of working in this way. My doctoral research shed light on the way that creative practitioners allow for an openness to come through, while being very conscious that projects must be delivered on time (and on budget). This way of working has influenced the way that I do research, becoming entangled with my own ethnographic research and understanding of ethnography, but this extends away from established models in educational and social science research which often assume a more linear process of question, theory, data and analysis. If it is to be meaningful, an ethnographic approach to creative practice must engage with different and conflicting ideas through research designs which encourage coproduction and transdisciplinarity, and which therefore enable dialogue and learning at all levels and across all stages.

\section{How might focusing on the theatre of the street develop rich understandings of people drawing on their communicative repertoires to produce creative work?}

The second question considers the context itself - the street arts production process. One of the most productive but also challenging aspects of conducting ethnographic research with street artists is in the multiple directions that each experience could have led in. The story selected by the performers as the basis for their production led me to explore its provenance and its geographical links and one of my thesis chapters focuses on Slovenian folklore, delving into the history of the region and the language. And when the folk tale is told through street arts production, it becomes a partial reflection of an imagined history: as imagined by multiple actors. My data led me to go beyond the bounded fieldwork period, to look backwards and consider trajectories of texts and material. It also pushed me to extend translanguaging towards the multimodal and embodied, encompassing the practices of the performers.

When the story is performed, it is in resemiotised form enabling it to be told in the street. De Certeau describes space as "practiced place" $(1984,117)$, stating, "the street geometrically defined by urban planning is transformed into a space by walkers" (ibid). For the performance, the street has been pre-defined by Ljubljana's city planning department, the sites determined by the theatre company negotiated with the city council and the festival legitimised. If city streets are transformed into space by those within it, street arts performance plays a particular role. Street arts performances are interventions in "public" places, making what Simpson describes as "significant interventions into the everyday life of cities" $(2011,416)$. The spaces "created" by street 
performers are liminal, like the practice itself, and as the festival title implies. The prevailing image of the street performer, performing outside, as a busker, as a juggler, as someone blowing giant bubbles contrasts with that of the performer performing inside, as an actor in the theatre, as a dancer in the ballet. Following street performers enables a particular lens on everyday activity: in public and in the street.

\section{How can short-term research be embedded within a longer-term commitment to working with research participants and collaborators?}

The third question is methodological and epistemological. The evolution of the research methodology to follow the arts organisation's work is discussed in more detail in a book chapter (Bradley 2017a) in which I conceptualise the "liquid" ethnographic approach underpinning my research as encompassing short-term, intensive ethnography, consolidated through active participation and engagement across a longer period of time. This active participation and engagement led to collaboration with Bev, artistic director, and we developed a series of collaborative projects (Migration and Home, AHRC, e.g. McKay and Bradley 2016 and Migration and Settlement, ESRC LSSI). Through working together, the nature of the research collaboration changed considerably.

In this chapter I have focused on how new understandings of communication are enabled through ethnographic approaches to creative practice. I considered translanguaging as a conceptual framework for understanding dynamic communicative practices in community arts and followed by considering the challenges and opportunities in short-term ethnography. I included a small excerpt of unexpected data, emerging from a conversation taking place in a taxi. In describing some of the processes involved in creating theatre for the street, the chapter demonstrates how ethnography as an approach to research enables insights into how people communicate over the course of creating work together. It makes the case for short-term and intensive bursts of ethnographic research within the context of a longer-term commitment to working with research participants, as offering the opportunity for data, and new questions, to emerge.

\section{Acknowledgements}

Thank you to Bev Adams, Faceless Arts and the Ana Monro Theatre. Thanks are also due to Louise Atkinson, Lou Harvey and James Simpson for their helpful critique of earlier drafts and to Sari Pöyhönen for her hospitality during the Ethnography with a Twist conference in February 2019 during which I explored these ideas. The ideas within this chapter were also developed through a Centre for Luxembourg Studies graduate seminar organised by Sarah Muller at the University of Sheffield. Jean Conteh is the wise colleague who provided food for thought on "ethnography" while I was a doctoral researcher. And credit where credit is due to Emmy who was my super-conference-companion and Izzy my super-fieldwork-companion. 


\section{References}

Adams, B. 2015. "Street Arts Winter Academy \#4 - Creating the European Federation of Education and Training in Street Arts". Circostrada. www.circostrada.org/sites/default/ files/ressources/files/cs-publication-4-en-2_final.pdf

Auer, P. 2019. “'Translanguaging' or 'doing languages'? Multilingual practices and the notion of 'codes"'. In Language(s): Multilingualism and Its Consequences, edited by J. MacSwan. Bristol: Multilingual Matters.

Barad, K. 2007. Meeting the Universe Halfway: Quantum Physics and the Entanglement of Matter and Meaning. Durham: Duke University Press.

Baynham, M., J. Bradley, J. Callaghan, J. Hanusova, and J. Simpson. 2015. "WP4 translanguaging business: Unpredictability and precarity in superdiverse inner city Leeds". Working Papers in Translation and Translanguaging. https://tlang.org.uk/working-papers/

Bradley, J. 2017a. "Liquid methodologies: Researching the ephemeral in multilingual street performance". In Researching Education in Multilingual Settings, edited by J. Conteh, 153-171. London: Bloomsbury.

Bradley, J. 2017b. "Translanguaging engagement: Dynamic multilingualism and university language engagement programmes". Bellaterra Journal of Teaching and Learning Language and Literature 10 (4): 9-31.

Bradley, J. 2018. "Translation and translanguaging in production and performance in community arts". $\mathrm{PhD}$ diss., University of Leeds.

Bradley, J., E. Moore, J. Simpson, and L. Atkinson. 2018. "Translanguaging space and creative activity: Theorizing collaborative arts-based learning". Language and Intercultural Communication 18 (1): 54-73.

Conteh, J., ed., 2017. Researching Education in Multilingual Settings: Ethnographic Principles in Qualitative Research. London: Bloomsbury.

Conteh, J., and S. Toyoshima. 2005. "Researching teaching and learning: Roles, identities and interview processes". English Teaching: Practice and Critique 4 (2): 23-34.

Copeland, F. 1933. "Zlatorog (A Slovene Folk Tale)". The Slavonic and East European Review 11 (33): 651-654.

Copland, F., and A. Creese. 2015. Linguistic Ethnography: Collecting, Analysing and Presenting Data. London and Los Angeles: SAGE.

de Certeau, M. 1984. The Practice of Everyday Life. Berkeley, Los Angeles and London: University of California Press.

García, O. 2020. "Foreword: Colabor and re-performances". In Translanguaging as Transformation: The Collaborative Construction of New Linguistic Realities, edited by E. Moore, J. Bradley, and J. Simpson. Bristol: Multilingual Matters.

García, O., and W. Li. 2014. Translanguaging. Language, Bilingualism and Education. Basingstoke: Palgrave Macmillan.

García, O., and R. Otheguy. 2019. "Plurilingualism and translanguaging: Commonalities and divergences". International Journal of Bilingual Education and Bilingualism. doi:10.1080/ 13670050.2019 .1598932

Geertz, C. 1973. The Interpretation of Cultures. New York: Basic Books Inc.

Geertz, C. 1998. "Deep hanging out". The New York Review of Books 45 (16): 69.

Grenfell, M., and K. Pahl. 2019. Bourdieu, Language-based Ethnographies and Reflexivity: Putting Theory into Practice. New York, Abingdon: Routledge.

Hammersley, M., and P. Atkinson. 1983. Ethnography: Principles in Practice. London: Tavistock.

Harvey, L. 2020. "Entangled trans-ing: Co-creating a performance of language and intercultural research". In Translanguaging as Transformation: The Collaborative Construction of New 
Linguistic Realities, edited by E. Moore, J. Bradley, and J. Simpson. Bristol: Multilingual Matters.

Hawkins, M. R., and J. Mori. 2018. "Considering 'trans-' perspectives in language theories and practices". Applied Linguistics 39 (1): 1-8.

Heller, M. 2008. "Doing ethnography". In The Blackwell Guide to Research Methods in Bilingualism and Multilingualism, edited by L. Wei and M. Moyer, 249-262. Malden: Blackwell.

Ingold, T. 2014. “That's enough about ethnography!” HAU: Journal of Ethnographic Theory 4 (1): 383-395.

Ingold, T. 2017. "Anthropology contra ethnography". HAU Journal of Ethnographic Theory 7 (1): $21-26$.

Jaspers, J. 2017. "WP226 the transformative limits of translanguaging”. Working Papers in Urban Language and Literacies. www.academia.edu/34532582/WP226_Jaspers_2017. _The_transformative_limits_of_translanguaging

Jones, A. 2016. "Introduction". Performance Research 21 (5): 1-11.

Jørgensen, J. N., M. Karrebæk, L. Madsen, and J. S. Møller. 2011. "Polylanguaging in superdiversity". Diversities 13 (2): 23-37.

Kress, G. 2005. "Gains and losses: New forms of texts, knowledge, and learning". Computers and Composition 22: 5-22.

Kusenbach, M. 2003. "Street phenomenology: The go-along as ethnographic research tool". Ethnography 4 (3): 455-485.

Kusters, A., M. Spotti., R. Swanwick, and E. Tapio. 2017. "Beyond languages, beyond modalities: Transforming the study of semiotic repertoires". International Journal of Multilingualism 14 (3): 219-232.

Li, W. 2018. "Translanguaging as a practical theory of language". Applied Linguistics 39 (1): 9-30.

MacLure, M. 2013. "The wonder of data". Cultural Studies - Critical Methodologies 13 (4): 228-232.

MacSwan, J. 2017. "A multilingual perspective on translanguaging”. American Educational Research Journal 54 (1): 167-201.

McKay, S., and J. Bradley. 2016. "How does arts practice engage with narratives of migration from refugees? Lessons from 'Utopia". Journal of Arts and Communities, Special Edition with Amnesty International on Arts, Activism and Human Rights 8 (1-2):31-46.

Miller, D. 2017. "Anthropology is the discipline but the goal is ethnography". HAU Journal of Ethnographic Theory 7 (1): 27-31.

Pennycook, A. 2016. "Mobile times, mobile terms: The trans-super-poly-metro movement". In Sociolinguistics: Theoretical Debates, edited by N. Coupland, 201-217. Cambridge: Cambridge University Press.

Pennycook, A. 2017. "Translanguaging and semiotic assemblages". International Journal of Multilingualism 14 (3): 269-282.

Pennycook, A., and E. Otsuji. 2015. Metrolingualism. Language in the City. Oxon: Routledge. Pink, S. 2009. Doing Sensory Ethnography. London: SAGE.

Pink, S., and J. Morgan. 2013. "Short-term ethnography: Intense routes to knowing". Symbolic Interaction 36 (3): 351-361.

Rampton, B., J. Maybin, and C. Roberts. 2014. "WP 125 methodological underpinnings of linguistic ethnography". Working Papers in Urban Language and Literacies. www.kcl.ac. $\mathrm{uk} / \mathrm{sspp} /$ departments/education/research/ldc/publications/workingpapers/abstracts/

WP125-Methodological-foundations-in-linguistic-ethnography.aspx

Rymes, B. 2014. Communicating Beyond Language. New York: Routledge. 
Shuman, A. 2011. "On the verge: Phenomenology and empathic unsettlement". The Journal of American Folklore 124 (493): 147-174.

Thomson, P., and H. Gunter. 2011. "Inside, outside, upside down: The fluidity of academic researcher 'identity' in working with/in school". International Journal of Research \& Method in Education 34 (1): 17-30.

Turner, V. 1969. The Ritual Process: Structure and Anti-Structure. Chicago, IL: Aldine.

Wells, N., C. Forsdick., J. Bradley, C. Burdett, J. Burns, M. Demossier, M. H. de Zárate, S. Huc-Hepher, S. Jordan, T. Pitman, and G. Wall. 2019. "Ethnography and modern languages". Modern Languages Open 1. http://doi.org/10.3828/mlo.v0i0.242 